\title{
The Effect of Implementing Flipped Classrooms on Iranian Junior High School Students' Reading Comprehension
}

\author{
Arash Hashemifardnia \\ Department of English, Faculty of Humanities, Shahrekord Branch, Islamic Azad University, Shahrekord, Iran \\ Ehsan Namaziandost \\ Department of English, Faculty of Humanities, Shahrekord Branch, Islamic Azad University, Shahrekord, Iran \\ Sajad Shafiee \\ Department of English, Faculty of Humanities, Shahrekord Branch, Islamic Azad University, Shahrekord, Iran
}

\begin{abstract}
This study investigated the effect of implementing flipped classrooms on Iranian junior high school students' reading comprehension. To this end, 50 Iranian pre-intermediate students were chosen and randomly assigned into two equal groups; one experimental group (flipped classroom) and one control group (traditional classroom). After that, both groups were pretested through a reading comprehension test. Then, the researchers put the respondents of the experimental group in a flipped classroom. The flipped classroom was equipped with Internet, computer and projector. The students were required to read each text before coming the class and discuss it with their classmates. On the other hand, the control group was taught in the traditional classroom. Before teaching each text, the researchers provided background knowledge for the control group and after teaching each text, the students were required to answer some questions related to the text. The whole treatment lasted 8 sessions of 50 minutes. In the last session, the post-test of reading comprehension was administered. The results of paired and independent samples t-tests indicated that there was a significant difference between the post-tests of the experimental and the control groups. The findings revealed that the experimental group significantly outperformed the control group $(p<.05)$ on the post-test.
\end{abstract}

Index Terms - flipped classrooms, traditional classrooms, reading comprehension

\section{INTRODUCTION}

As inverted or flipped models have become increasingly prevalent in the instructional literature and more widely implemented by practitioners over the past several years (Moranski \& Kim, 2016), the need to investigate the effects of flipped classrooms on language learning is crucially important. The flipped classroom is a pedagogical strategy that reverses the traditional classroom process by delivering the instructional content usually, but not always, online before class and then engaging learners in interactive group learning and/or critical problem solving activities that are carried out under the teachers' guidance during the class (Herreid \& Schiller, 2013).

Flipped classrooms are believed to be very useful for teaching and learning. Some pedagogical benefits of the flipped classroom were determined by some researchers. These benefits include (1) students and instructors' positive perceptions of the active learning environment (e.g., Butt, 2014; Gilboy, Heinerichs, \& Pazzaglia, 2015), (2) more active engagement during class (e.g., Deslauriers, Schelew, \& Wieman, 2011), and (3) superior achievement on formative/summative assessments (e.g., Amresh, Carberry, \& Femiani, 2013). For example, when Love, Hodge, Grandgenett, and Swift (2014) implemented a flipped linear algebra course, the majority of students reported that the approach helped them develop a deeper understanding of the content. Amresh et al. (2013) reported that students in a flipped introductory computer programming course performed significantly better than did students in a comparable traditional course design on assignments and exams.

The pedagogical relevance of the flipped classroom is supported by a range of student-centered learning theories in the field of educational psychology (Bishop \& Verleger, 2013), including cooperative learning (Slavin, 1991), collaborative learning (Goodsell, Maher, Tinto, Smith, \& MacGregor, 1992), peer tutoring (Tabacek, McLaughlin, \& Howard, 1994), peer assisted learning (Topping \& Ehly, 1998), problem-based learning (Barrows, 1996), and active learning (Michael, 2006).

Recently, the development of educational technology has allowed flipped classrooms to be easily adopted in higher education contexts (Hamdan, McKnight, McKnight, \& Arfstrom, 2013). This learning environment can be characterized as student-centered-students are expected to come to class having already gained the knowledge necessary to actively engage in problem-solving activities with their peers. Throughout the cycle of instruction, they maintain an active role at the center of learning. The practice is based on the assumptions that meaningful interaction 
among peers encourages knowledge building and that teachers can provide more timely and personalized guidance and feedback during in-class activities (Kim, Park, Jang, \& Nam, 2017; Zarrinabadi, \& Ebrahimi, 2018).

Regarding the importance and effectiveness of flipped classroom, it is supposed that it can improve EFL learners' reading comprehension. Comprehension involves constructing meaning that is reasonable and accurate by connecting what has been read to what the reader already knows and thinks about all of this information until it is understood (as cited in Mohammadi \& Davarbina, 2015). According to Block and Pressley (2002), comprehension is the final goal of reading instruction. One of the most important components of English performance, particularly in academic setting is English reading ability (Huckin, Haynes, \& Coady, 1993).

Therefore, reading comprehension is the process of understanding and constructing meaning from a piece of text (Brown, 2007). So, students need good reading skill for acquiring knowledge and learning new information. However, we can see that most students are not good enough to do so. Because most of the teaching in EFL classrooms still emphasizes teacher-centered, teacher directed instruction in order to get good grades in English, and to this end, teachers might bring the competition into the classroom (as cited in Mohammadi \& Davarbina, 2015). Such a traditional instructional approach causes competitive learning and individual performance in the classroom teaching (Robert \& Slavin, 2005). To reduce teacher-centered reading instruction, this study aimed to investigate the impacts of flipped classroom- a student-centered classroom- on improving Iranian EFL learners' reading comprehension (Mohammadi \& Davarbina, 2015)

\section{REVIEW OF THE LITERATURE}

\section{A. Theoretical Background}

\section{The Flipped Classroom}

The "flipped classroom" is a new catch phrase in education, but it is not a completely novel idea. Teachers often assign reading to be done at home, and then expect students to engage in conversation about the reading in class. This design could be classified as an inverted classroom (Strayer, 2012). However, a few key characteristics distinguish the flipped classroom from an inverted classroom. In the flipped classroom, students watch video-recorded lectures outside of class, thus increasing time for active learning and practice to occur in the class (Strayer, 2012). While implementation of this method may look slightly different for each teacher, essentially "the 'flipped' part of the flipped classroom means students watch or listen to lessons at home and do their 'homework' in the class”' (Fulton, 2012, p. 13).

Online learning has various definitions. Historically, video lectures were created to provide curriculum access to individuals who lived far from school. Teachers began realizing videos not only helped off-site students, but also students who were present during lectures (Cascaval, Fogler, Abrams, \& Durham, 2008). Online classes gained popularity in the past decade, especially at the college level. However, students commonly complained about limited interaction and communication in purely online classes (Gecer \& Dag, 2012). Flipping the classroom involves online learning through a series of video lectures, but it is supported by face-to-face classroom discussions and individual help. Thus, the flipped classroom is different from traditional online learning environments.

Traditional classroom lectures often follow a one-pace-fits-all philosophy. Teachers may adjust their lectures based on the students' feedback, but some students will undoubtedly find the pace swift, while others find it slow. Video lectures provided through the flipped classroom model allow students to fast forward through examples they already understand, or pause and rewind to revisit topics which may require more processing time (Goodwin \& Miller, 2013). Videos allow lectures to be broken into pieces, as opposed to traditional instruction which often contains a large volume of content delivered at one time (Brecht \& Ogilby, 2008).

Khan (2012), a widely recognized online educator, popularized the flipped classroom through his website, Khan Academy. This website contains over 4120 short educational videos, most detailing a specific math concept (Thomas, 2013). Khan works on the problems step by step on each video. "Khan's idea was that youngsters would watch the videos at home and work on the problems in class, essentially 'flipping' the classroom" (Kronholz, 2012, p. 25). Khan seeks to change the way people think about education, noting "the old classroom model simply does not fit our changing needs" (Khan, 2012, p. 1).

Many schools have used Khan's videos to flip the classroom. Greg Green, principal at Clintondale Community Schools in Michigan, commended the flipped classroom for its ability to assist students who do not get homework help at home (Finkel, 2012). Students now receive guidance at home in the form of video lectures, and can directly interact with teachers and peers during class time to get answers to their questions. Teachers utilizing Khan Academy to flip their classrooms realize they often work harder during the school day as they are always moving around and interacting with students. It must be noted Khan Academy is not meant as a fix-all. Math teacher Courtney Cadwell commented Khan "is not great at helping kids conceptualize math" (Kronholz, 2012, p. 26). Video lectures need to be supplemented with activities which encourage discussion and emphasize the application side of mathematics. When flipping the classroom, teachers must constantly interact with students, adjust instruction on the fly, and design activities which complement the videos.

\section{Reading Comprehension}

Comprehension of the text is the main goal of the readers. Puskorius (2011) stated that comprehension in reading is the understanding that one acquires from text. It is the process in which meaning is constructed and is a main goal of 
reading instruction for students. According to Syatriana (2011), reading comprehension means understanding what has been read. It is an active thinking process that depends not only on comprehension skill but also students` experience, and prior knowledge comprehension involves understanding the vocabulary seeing the relationship among words and concepts, organizing ideas, recognizing author's making judgment, and evaluating. Along the same line, reading comprehension is defined by Badr El Deen (2011) as the ability to communicate a text leading to an integrated process that involves decoding vocabulary and sentences, employing prior knowledge relevant to the text and using cognitive and meta-cognitive strategies in order to make sense and to get the target message the author wants to convey.

Abu Nejmeh (2011) asserted that reading comprehension is not just understanding words, sentences, or even texts, but involves a complex integration of the reader prior knowledge language proficiency and meta-cognitive strategies. Moreover, reading comprehension is the act of thinking and constructing meaning before, during and after reading by integrating the information presented by the author with the reader's background knowledge (Kirmizi, 2010). A common definition for teachers might be that comprehension is a process in which readers construct meaning by interacting with text through the combination of prior knowledge and previous experience, information in the text, and the stance the reader takes in relationship to the text (Pardo, 2004).

It is clear that prior knowledge, meaning and cognitive strategies are core words in the previously mentioned definitions (Alharbi, 2015). To sum up, simple comprehension of meaning of words is not sufficient to comprehend a text while reading. To achieve comprehension in reading, effective readers need to implement such practices as relating their background experience with the text, summarizing information, drawing conclusions, and posing questions at the text (Kirmizi, 2010). Kirmizi (2010) confirmed that comprehension involves constructing meaning that is reasonable and accurate by connecting what has been read to what the reader already knows and thinks about all of this information until it is understood. Comprehension is the final goal of reading instruction.

\section{B. Empirical Background}

Some studies have been conducted on flipped classroom to measure its effects. For instance, Ching Lin and Chen (2016) aimed to verify and to understand the effects of flipped classroom on the learning effectiveness, while using learning satisfaction as the mediator. The findings showed that: 1) both the instructors and students of technical and vocational colleges (the first half) believed that flipped learning has a positive effect on learning satisfaction; while the students of the second half of technical a vocational colleges believed that flipped learning has a negative effect on learning satisfaction; 2) both the instructors and students of technical and vocational colleges (both halves) believed that flipped learning has a significant positive effect on learning effectiveness; and 3) both the instructors and students of technical and vocational colleges (the first half) believed that flipped learning has a positive effect on learning effectiveness; while the instructors and students of the second half of technical and vocational colleges believed that flipped learning has a negative effect on learning effectiveness. Summarizing the above, learning satisfaction has a partial mediating effect.

Kim, Park, Jan, and Nam (2017) investigated the cognitive effects of the flipped classroom approach in a contentbased instructional context by comparing second language learners' discourse in flipped vs. traditional classrooms in terms of (1) participation rate, (2) content of comments, (3) reasoning skills, and (4) interactional patterns. Learners in two intact classes participated and were taught in either a flipped classroom or a traditional classroom. In the flipped class, the learners listened to an online lecture before class and participated in a small-group discussion in class. In contrast, the learners in the traditional class listened to a teacher-led lecture in class and then immediately participated in a small-group discussion in class. The learners' discussions were audio recorded. Quantitative and qualitative analyses indicated no difference in participation rates; however, the students in the flipped classroom produced more cognitive comments involving deeper information processing and higher-order reason in $\mathrm{g}$ skills and showed more cohesive interactional patterns than did the students in the traditional classrooms. The results indicated that flipped classrooms can effectively promote higher-order thinking processes and in-depth, cohesive discussion in the contentbased second language.

\section{RESEARCH QUESTION}

This study aimed to answer the following research question:

RQ. Does implementing flipped classrooms have any significant effect on Iranian junior high school students' reading comprehension?

Based on the above-mentioned research question, the following null hypothesis was tested:

HO. Implementing flipped classrooms does not have any significant effect on Iranian junior high school students' reading comprehension.

\section{METHOD}

\section{A. Participants}

The participants of this study were 50 pre-intermediate language learners who were selected among 70 third grade junior high school students at Saadi high school, Baghmalek, Khuzestan, Iran based on non-random sampling. Their 
level of English language proficiency was determined on the basis of their scores on the Oxford Quick Placement Test (OQPT). The participants' age range was 14 to 15 . Only males were participated in the current study. They have been studying English as a foreign language for at least three years. The learners were randomly divided into one experimental group (flipped classroom) and one control group (traditional classroom). There were 25 participants in each group.

\section{B. Instruments}

The first instrument which was employed in the present study to homogenize the participants was the OQPT. It helped the researcher to have a greater understanding of what level (i.e., elementary, pre-intermediate, intermediate) his participants were at. According to this test, the learners whose scores were between 30 and 39 (out of 60) were considered as the pre-intermediate learners.

The second instrument was a reading comprehension pre-test. To realize the current participants' reading comprehension level, a researcher-made pre-test was designed based on the students' course book (Prospect Book 3). It consisted of 20 objective items including short answer and true/false. The validity of the pre-test was confirmed by a panel of English experts. It was piloted on a similar group in another high school. It should be mentioned that the reliability indexes of the pre-test was calculated through KR-21 formula $(\mathrm{r}=.811)$.

The third instrument of the current study was a reading comprehension post-test- the modified version of the pre-test was used as the post-test. All characteristics of the post-test were similar to the pre-test in terms of form and number of the items. The only difference was that the order of the questions were changed to wipe out the probable recall of pretest answers. The post-test was regarded both valid and reliable since it was the modified version of the pre-test (the validity and reliability of the pre-test were reported above). The post-test was administered to determine the effects of the treatment on the participants' reading comprehension.

\section{Data Collection Procedure}

To conduct the present study, the researcher attended the above-mentioned junior high school and administrated the OQPT to 70 Iranian third grade junior high school students to determine their level of English proficiency. The researcher selected 50 pre-intermediate students and randomly divided them into two groups, namely; one experimental group (flipped classroom) and one control group (traditional classroom). Then, both groups were pretested through a reading comprehension test. After that, the researcher put the participants of the experimental group in a flipped classroom. The flipped classroom was equipped with Internet, computer and projector and participants in this classroom were allowed to bring their Smartphones to the classroom in order to use them during learning. The students in the flipped classroom were given 5 reading texts from Prospect Book 3. Each text was sent to the students through Email, What's App or Telegram. It should be noted that three days before each session, one text had been sent to them via Internet. It is worth mentioning that the audio file of each text was sent to the students in a Telegram group. When the materials were presented in the group, some activities were done including brainstorming, questions /answers, finding the main idea, and paraphrasing to teach the texts to the students.

In addition, the students were required to read each text before coming the class and discuss it with their classmates. Besides, the students listened to the audio text several times at home via their Smartphones. In the flipped classroom, when the students attended the class, the teacher elicited some information related to the text from them, asked them some questions and gave them a test. He also randomly asked some students to read the text and say its main idea.

The flipped classroom refers to a strategy of blended learning in which "homework" precedes class time. Accordingly, participants of the experimental group had the homework before attending the class. The teacher in the experimental group was a facilitator and coordinator in learning process.

On the other hand, the control group was taught in the traditional classroom. The traditional classroom was deprived of the Internet and the students were taught in the classroom rather than out of the classroom. Before teaching each text, the researcher provided background knowledge for the students and after teaching each text, the students were required to answer some questions related to the text. This procedure continued till the last session. The whole treatment lasted 8 sessions of 50 minutes. In the first and the second sessions, the OQPT and pre-test were administered respectively. During 5 sessions, the reading texts were trained to the students and in the last session, both groups took the post-test of reading comprehension.

\section{Data Analysis}

The collected data through the aforesaid procedures were analyzed and interpreted according to the objective of the study. Firstly, Kolmogorov-Smirnov (K-S) test was used to check the normality of the gathered data. Then, the descriptive statistics were calculated and reported. Finally, paired samples and independent samples t-tests were run to determine the effectiveness of flipped classrooms on Iranian EFL learners' reading comprehension.

\section{RESULTS}

The obtained results are displayed in the following tables. 
TABLE 1:

ONE-SAMPLE KOLMOGOROV-SMIRNOV TEST (GROUPS' PRE AND POST-TESTS)

\begin{tabular}{|c|c|c|c|c|c|}
\hline & & preex & Postex & precont & Postcont \\
\hline $\mathrm{N}$ & & 25 & 25 & 25 & 25 \\
\hline \multirow[t]{2}{*}{ Normal Parameters ${ }^{\mathrm{a}, \mathrm{b}}$} & Mean & 12.4000 & 18.8833 & 13.3833 & 14.7167 \\
\hline & Std. Deviation & 3.78310 & 6.71727 & 5.11923 & 5.70486 \\
\hline \multirow[t]{3}{*}{ Most Extreme Differences } & Absolute & .175 & .143 & .127 & .150 \\
\hline & Positive & .069 & .143 & .086 & .150 \\
\hline & Negative & -.175 & -.127 & -.127 & -.150 \\
\hline Kolmogorov-Smirnov Z & & 1.352 & 1.108 & .982 & 1.164 \\
\hline Asymp. Sig. (2-tailed) & & .052 & .171 & .289 & .133 \\
\hline
\end{tabular}

a. Test distribution is Normal.

b. Calculated from data.

Table 1 shows that the statistics of scores is normal as the results obtained from using Statistical Package for Social Science (SPSS) software, version 22. In this case, the parametric statistics like independent samples t-test and paired samples t-test were used to get the final results.

TABLE 2:

GROUP STATISTICS (PRE-TEST OF BOTH GROUPS)

\begin{tabular}{llllll}
\hline & VAR00005 & $\mathrm{N}$ & Mean & Std. Deviation & Std. Error Mean \\
\hline Preex & 1.00 & 25 & 13.3833 & 3.78310 & .48840 \\
\hline & 2.00 & 25 & 12.4000 & 5.11923 & .66089 \\
\hline
\end{tabular}

In Table 2, the descriptive statistics of both groups is presented. The means of both groups are almost equal. The experimental group's mean score is 13.3833 and the control group's mean score is 12.4000 . This means that the both groups are somehow similar since they are homogeneous at the beginning of the treatment.

TABLE 3:

INDEPENDENT SAMPLES T-TEST (PRE-TEST OF BOTH GROUPS)

\begin{tabular}{|c|c|c|c|c|c|c|c|c|c|c|}
\hline & & \multicolumn{2}{|c|}{$\begin{array}{l}\text { Levene's Test for } \\
\text { Equality of Variances }\end{array}$} & \multicolumn{7}{|c|}{ t-test for Equality of Means } \\
\hline & & & & & & & & & \multicolumn{2}{|c|}{$\begin{array}{l}95 \% \text { Confidence } \\
\text { Interval of the } \\
\text { Difference }\end{array}$} \\
\hline & & $\mathrm{F}$ & Sig. & $\mathrm{T}$ & Df & $\begin{array}{l}\text { Sig. (2- } \\
\text { tailed) }\end{array}$ & $\begin{array}{l}\text { Mean } \\
\text { Difference }\end{array}$ & $\begin{array}{l}\text { Std. Error } \\
\text { Difference }\end{array}$ & Lower & Upper \\
\hline \multirow[t]{2}{*}{ Preex } & $\begin{array}{l}\text { Equal variances } \\
\text { assumed }\end{array}$ & 3.852 & .052 & -1.197 & 118 & .234 & -.98333 & .82177 & -2.61066 & .64400 \\
\hline & $\begin{array}{l}\text { Equal variances not } \\
\text { assumed }\end{array}$ & & & -1.197 & 108.638 & .234 & -.98333 & .82177 & -2.61212 & .64545 \\
\hline
\end{tabular}

In Table 3, an independent samples t-test was used to show the scores of both groups on the pre-test. Since Sig (.234) is greater than 0.05 , the difference between the groups is not significant at $(\mathrm{p}<0.05)$. In fact, they performed the same on the pre-test.

TABLE 4:

GROUP STATISTICS (POST-TEST OF BOTH GROUPS)

\begin{tabular}{llllll}
\hline & VAR00005 & $\mathrm{N}$ & Mean & Std. Deviation & Std. Error Mean \\
\hline Postex & 1.00 & 25 & 18.8833 & 6.71727 & .86720 \\
& 2.00 & 25 & 14.7167 & 5.70486 & .73649 \\
\hline
\end{tabular}

Table 4 reveals the descriptive statistics of both groups on the post-test. The means of the groups are different. The experimental group's mean score is 18.8833 and the control group's mean score is 14.7167 . This means that the experimental group outperformed the control group. 
TABLE 5:

INDEPENDENT SAMPLES T-TEST (THE POST-TEST OF BOTH GROUPS)

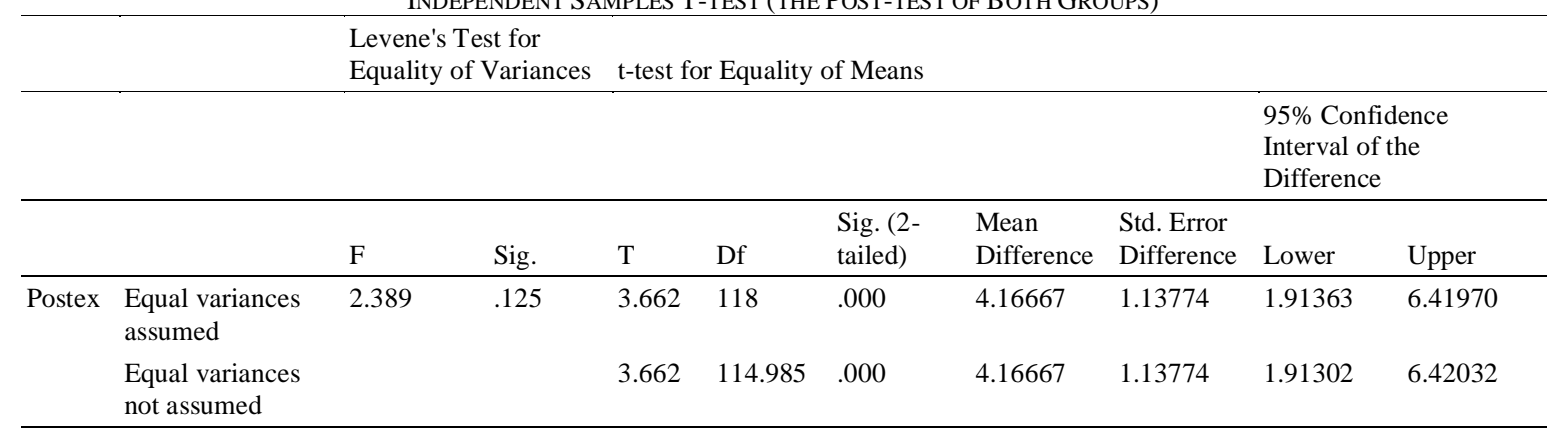

Table 5 indicates that the difference between both groups is significant at $(\mathrm{p}<0.05)$. In fact, the experimental group outperformed the control group on the post-test.

TABLE 6:

PAIRED SAMPLES STATISTICS (PRE AND POST-TESTS OF BOTH GROUPS)

\begin{tabular}{llllll}
\hline & & Mean & N & Std. Deviation & Std. Error Mean \\
\hline Pair 1 & Preex & 13.3833 & 25 & 3.78310 & .48840 \\
& Postex & 18.8833 & 25 & 6.71727 & .86720 \\
\hline Pair 2 & Precont & 12.4000 & 25 & 5.11923 & .66089 \\
& Postcont & 14.7167 & 25 & 5.70486 & .73649 \\
\hline
\end{tabular}

Based on the descriptive statistics in the above table, the mean scores of the experimental group on the pre and posttests are 13.3833 and 18.8833 respectively. The control groups' mean scores on the pre and post-tests are 12.4000 and 14.7167 respectively.

TABLE 7:

PAIRED SAMPLES T-TEST (PRE AND POST-TESTS OF BOTH GROUPS)

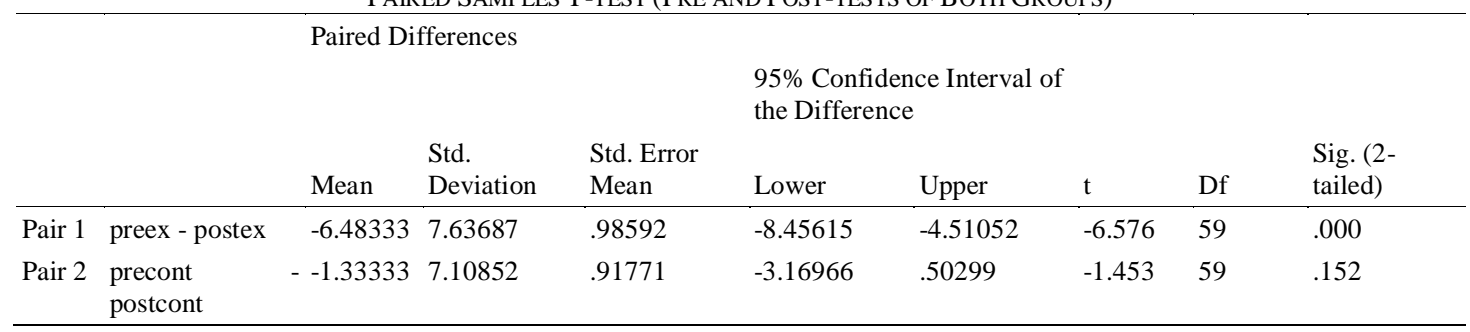

In the table above, a paired samples t-test is used to compare the pre and post-tests of each group. Since Sig (.000) is less than 0.05 , the difference between the pre-test and post-test of the experimental group is significant. Since Sig (.152) is greater than 0.05 , the difference between the pre-test and post-test of the control group is not significant.

\section{DISCUSSION}

In this part the research question "Does implementing flipped classrooms have any significant effect on Iranian junior high school students' reading comprehension?" is answered based on the results obtained in the tables above. After collecting the data, the researcher used paired samples t-test and independent samples t-test to analyze them in order to find out the effectiveness of flipped classrooms on the students' reading comprehension. The findings showed that the students who received instruction through flipped classrooms had better performance compared to those who were trained through traditional classrooms. The results statistically revealed that experimental group significantly did better than the control group $(p<.05)$. Therefore, the null hypothesis of the study "Implementing flipped classrooms does not have any significant effect on Iranian junior high school students' reading comprehension" was rejected. Participants in the flipped classrooms were highly motivated to learn because of the available facilities. Flipped learning is generally found to increase motivation (Bormann, 2014). Not only did they enjoy learning, but also they felt satisfied with what they learned. In fact, the experimental group gained higher scores on their post-test. This may be due to some appealing features the flipped classrooms have.

The flipped class can be more interactive than the traditional lecture; it can encourage contacts between students and teachers; it can develop reciprocity and cooperation among students, and it can emphasize time on task. As the researcher observed, in the flipped classroom, during class time, students engaged in discussions, activities, problem solving, and group work. Since students had prior knowledge, they could learn the lesson more easily. 
The major difference between flipped and traditional classrooms is the timing of content learning; students in a flipped classroom learn the content before class in their own private time and space and at their own pace, while in traditional classroom students learn the lesson in class in a way and at a pace that are determined by the instructor. Therefore, the rich cognitive activity (e.g., in-depth information processing and higher-order thinking processes) observed in this study may have been due to the fact that the students had more time to think about the content and activate relevant prior knowledge related to the content.

The cognitive load theory (Sweller, 2007) developed in the field of educational psychology supports this claim. According to this theory, learners" "cognitive capacity in working memory is limited, so that if a learning task requires too much capacity, learning will be hampered" (de Jong, 2010, p. 105). Hence, the available knowledge structures in long-term memory, or a large, permanent store of organized information, are essential for preventing working memory overload and for guiding cognitive processes.

Previous researches (e.g., Lawless \& Kulikowich, 1996; Scheiter, Gergets, Vollmann, \& Catrambone, 2009) has consistently reported that students with higher levels of prior knowledge utilize deeper processing strategies because the prior knowledge guides their information selection and thus reduces their cognitive load during learning. In the current study, the traditional students who learned the content on the same day may not have had enough time to expand their knowledge and establish the schemas before the discussion. Hence, their discussion would not have been supported by executive guidance, which would explain why the students remained at a superficial level of information processing and strategies.

The results of this study indicate that the students in the flipped classroom interacted more deeply and cohesively than the students in the traditional classroom. The obtained results are in line with Kim, Park, Jan, and Nam (2017) who investigated the cognitive effects of the flipped classroom approach in a content-based instructional context by comparing second language learners' discourse in flipped vs. traditional classrooms. Quantitative and qualitative analyses indicated that the students in the flipped classroom produced more cognitive comments involving deeper information processing and higher-order reasoning skills and showed more cohesive interactional patterns than did the students in the traditional classrooms. The results indicated that flipped classrooms can effectively promote higher-order thinking processes and in-depth, cohesive discussion in the content-based second language.

\section{CONCLUSION}

The results indicated that Iranian EFL learners can benefit from attending flipped classrooms. Based on the findings of the present study, it can be concluded that the implementing of flipped classrooms in teaching and learning can produce positive results because they could absorb students in learning English. The positive effects of using flipped classrooms became obvious after the treatment. Here, it can be claimed that receiving instruction through using flipped classrooms can facilitate English learning. Flipped classrooms can make the students independent and help them learn how to study out of the classroom. To become self-directed learners, students must learn to assess the demands of the task, evaluate their own knowledge and skills, plan their approach, monitor their progress, and adjust their strategies as needed flipped lecture checks on component skill and gives the opportunities to assess, apply and discuss previously acquired knowledge (Raine \& Gretton, 2017). Regarding the effectiveness and importance of the flipped classrooms, they are recommended to be implemented in educational environments. In this study, flipped classrooms had some benefits for the students; these benefits may be attributable to the executive guidance based on knowledge schema that was established before class through pre-learning.

\section{REFERENCES}

[1] Abu Nejmeh, S. (2011). Integrating higher order thinking skills on the tenth graders to improve learners' achievement in reading comprehension in Jenin district (Unpublished Master's Thesis). An-Najah National University, Palestine.

[2] Alharbi, A. M. (2015). Building vocabulary for language learning: approach for esl learners to study new vocabulary. Journal of International Students, 5(4), 501-511.

[3] Amresh, A., Carberry, A. R., \& Femiani, J. (2013). Evaluating the effectiveness of flipped classrooms for teaching CS1. In 2013 IEEE Frontiers in Education Conference (pp. 733-735). Oklahoma City: IEEE.

[4] Badr El-Deen, Z. (2009). The effectiveness of assisted extensive on developing reading comprehension strategies for ninth graders in Gaza governorate (Unpublished Master's Thesis). Islamic University-Gaza- Palestine.

[5] Barrows, H. S. (1996). Problem-based learning in medicine and beyond: A brief overview. New Directions for Teaching and Learning, 68(5), 3-12.

[6] Bishop, J. L., \& Verleger, M. A. (2013). The flipped classroom: a survey of the research. In ASEE National Conference Proceedings, Atlanta, GA.

[7] Block, C., \& Pressley, M. (2002). Comprehension instruction: Research-based best practices. New York: Guilford Press.

[8] Brecht, H. D., \& Ogilby, S. M. (2008). Enabling a comprehensive teaching strategy: Video lectures. Journal of Information Technology Education, 7(3), 71-86.

[9] Brown, D. (2007). Principles of language learning and teaching (5th ed.). NJ: Prentice Hall.

[10] Butt, A. (2014). Student views on the use of a flipped classroom approach: Evidence from Australia. Business Education \& Accreditation, 6(4), 33-43. 
[11] Cascaval, R. C., Fogler, K. A., Abrams, G. D., \& Durham, R. L. (2008). Evaluating the benefits of providing archived online lectures to in-class math students. Journal of Asynchronous Learning Networks, 12(4), 61-70.

[12] Ching Lin, P., \& Chen, H. (2016). The effects of flipped classroom on learning effectiveness: Using learning satisfaction as the mediator. World Transactions on Engineering and Technology Education, 14(2), 231-244.

[13] de Jong, T. (2010). Cognitive load theory, educational research, and instructional design: Some food for thought. Instructional Science, 38, 105-134.

[14] Deslauriers, L., Schelew, E., \& Wieman, C. (2011). Improved learning in a large-enrollment physics class. Science, 33(10), 862-864.

[15] Finkel, E. (2012). Flipping the script in K12. District Administration Magazine, 48(10), 28- 34.

[16] Fulton, K. (2012). Upside down and inside out: Flip your classroom to improve student learning. Learning \& Leading with Technology, 39(8), 12-17.

[17] Gecer, A., \& Dag, F. (2012). A blended learning experience. Educational Sciences: Theory and Practice, 12(1), 438-442.

[18] Gilboy, M., Heinerichs, S., \& Pazzaglia, G. (2015). Enhancing student engagement using the flipped classroom. Journal of Nutrition Education and Behavior, 47, 5, 109-114.

[19] Goodsell, A. S., Maher, M. R., Tinto, V., Smith, B. L., \& MacGregor, J. (1992). Collaborative learning: A sourcebook for higher education. University Park, PA: National Center on Postsecondary Teaching, Learning, and Assessment, Pennsylvania State University.

[20] Goodwin, B., \& Miller, K. (2013). Evidence on flipped classrooms is still coming in. Educational Leadership, 70(6), 78-80.

[21] Hamdan, N., McKnight, P., McKnight, K., \& Arfstrom, K. M. (2013). A review of flipped learning. Retrieved July 10, 2017, from http://www.flippedlearning.org.

[22] Herreid, C. F., \& Schiller, N. A. (2013). Case studies and the flipped classroom. Journal of College Science Teaching, 42(5), 62-66.

[23] Huckin, T. N., Haynes, M., \& Coady, J. (1993). Second language reading and vocabulary learning. New York, NY: Ablex Pub. Co.

[24] Khan, S. (2012). The one world schoolhouse. Education reimagined. New York: Twelve.

[25] Kim, J., Park, H., Jang, M., \& Nam, H. (2017). Exploring flipped classroom effects on second language learners' cognitive processing. Foreign Language Annals, 50(2), 260-284.

[26] Kirmizi, F. (2010). Relationship between reading comprehension strategy use and daily free reading time. Procedia Social and Behavioral Sciences, 2, 4752-4756.

[27] Kronholz, J. (2012). Can Khan move the bell curve to the right? Education Digest, 78(2), 23-30.

[28] Lawless, K. A., \& Kulikowich, J. M. (1996). Understanding hypertext navigation through cluster analysis. Journal of Educational Research, 14, 385-399.

[29] Love, B., Hodge, A., Grandgenett, N., \& Swift, A. W. (2014). Student learning and perceptions in a flipped linear algebra course. International Journal of Mathematical Education in Science and Technology, 45, 2, 317-324.

[30] Michael, J. (2006). Where's the evidence that active learning works? Advances in Physiology Education, 30(6), $159-167$.

[31] Mohammadi, A., \& Davarbina, M. (2015). The effect of cooperative learning techniques on reading comprehension ability of Iranian EFL learners. International J. Soc. Sci. \& Education, 5(3), 525-531.

[32] Moranski, K., \& Kim, F. (2016). Flipping lessons in a multi-section Spanish course: Implications for assigning explicit grammar instruction outside of the classroom. Modern Language Journal, 100 (7), 830-852.

[33] Pardo, L. (2004). What every teacher needs to know about comprehension. International Reading Association, 58(3), $272-280$.

[34] Puskorius, R. (2011). Reading comprehension strategies for elementary students. Retrieved December1, 2017, from: http://createcomputelearn.com/2013/08/08/comrehension-strategies/.

[35] Raine, D., \& Gretton, S. (2017). The flipped classroom, a teaching enhancement fund report. Centre for Interdisciplinary Science University of Leicester. Available at: http://docplayer.net/24689752-The-flipped-classroom.html.

[36] Robert, G., \& Slavin, R. E. (2005). Story retell: A fluency-based indicator of reading comprehension. School Psychology.

[37] Scheiter, K., Gerjets, P., Vollmann, B., \& Catrambone, R. (2009). The impact of learner characteristics on information utilization strategies, cognitive load experienced, and performance in hypermedia learning. Learning and Instruction, 19, 387401.

[38] Slavin, R. E. (1991). Synthesis of research of cooperative learning. Educational Leadership, 48(5), 71-82.

[39] Strayer, J. F. (2012). How learning in an inverted classroom influences cooperation, innovation and task orientation. Learning Environments Research, 15(2), 171-193.

[40] Sweller, J. (2007). Evolutionary biology and educational psychology. In J. S. Carlson \& J. R. Levin (Eds.), Psychological perspectives on contemporary educational issues (pp. 165-175). Greenwich, CT: Information Age.

[41] Syatriana, E. (2011). Developing the students' reading comprehension through cognitive reading strategies of the first year students of SMAN 16 Makassar (Unpublished master's thesis). Indonesia.

[42] Tabacek, D. A., McLaughlin, T. F., \& Howard, V. F. (1994). Teaching preschool children with disabilities tutoring skills: Effects on pre-academic behaviors. Child \& Family Behavior Therapy, 16(8), 43-63.

[43] Thomas, I. M. (2013). Sal Khan is a can-do guy. The Costco Connection, 28(8), 30-33.

[44] Topping, K., \& Ehly, S. (1998). Peer assisted learning. Oxford: Routledge.

[45] Zarrinabadi, N., \& Ebrahimi, A. (2018). Increasing peer collaborative dialogue using a flipped classroom strategy. Innovation in Language Learning and Teaching, 1-10.

Arash Hashemifardnia was born in Khouzestan Province of Iran in 1987. He holds a master's degree in TEFL from Islamic Azad University of Ahvaz. He is a PhD student in TEFL at Islamic Azad University of Shahr-e Kord. His major research interests are 
teacher education, action research, mixed methods research, second language acquisition, and task-based language learning and teaching. He has published a number of articles in his areas of interest in academic journals.

Ehsan Namaziandost was born in Shiraz Province of Iran in 1985. He holds an MA degree in TEFL from Islamic Azad University of Ahvaz. Now, he is a Ph.D. student in TEFL at Islamic Azad University of Shahr-e Kord. His main interests of research are second language acquisition, EFL teaching, teaching and testing, teaching speaking, communication and language learning strategies. His research papers and articles have been published by different international journals.

Sajad Shafiee holds a Ph.D. in TEFL. He is currently an assistant professor in the Department of English Language Teaching at two universities: 1) Islamic Azad University, Shahr-e Kord Branch, Shahr-e Kord, Iran 2) Islamic Azad University, Khorasgan (Isfahan) Branch, Isfahan, Iran. 